\title{
THE SETTLEMENT OF CONTRACT NEGOTIATION DISPUTES: A BUSINESS VIEWPOINT
}

\section{Bernard H. Fitzpatrick*}

The search for some formula for the settlement of labor disputes has, of late, occupied the public mind to too great an extent. This is singularly unfortunate because it diverts the public mind from its proper path-the search for sound principles of union organization. The plain truth of the matter is that we are unable to formulate any really rational principles for the settlement of labor disputes because we have no really rational and consistent notions of what labor unions are and what they are supposed to accomplish. Since we have no adequate notions on these subjects, we cannot proceed to examine scientifically the next basic question, "What powers and privileges do labor unions need to accomplish their proper purposes?" And if we are not prepared to answer that question we cannot answer its sequel, "What powers and privileges should be denied to labor unions on the ground that they are non-functional and hence arbitrary?"

Basically, national success in the settlement of labor disputes depends not on such devices as "better mediation machinery," "labor courts" of vague jurisdiction, "cooling-off periods," nor even on those sound but ill-defined notions, "collective bargaining" and "proper human relations"; it depends on the discovery and employment of rational principles for the conduct of parties to labor negotiations. We do not have such principles.

In the absence of accepted principles which at least delineate the major functions and, hence, the powers of unions, talking about settlement machinery is roughly comparable to taking aspirin to relieve recurrent headaches. True, the aspirin may relieve some of the pain, but it will never cure faulty vision, which may well be the cause of the headaches. Moreover, in the limited understanding of the writer, aspirin, taken long enough and in large enough doses, will produce organic damage in the human body; and we may well wonder, listening to recent election returns and to the wilder suggestions for modification of our labor laws, whether we are not now suffering from overdoses of "dispute settlement" administered to the body politic in the last dozen years.

Therefore, in order to avoid a mere treatise on "aspirin," which will never set the body politic back on its feet, this paper will be devoted first to a discussion of the

- A.B. 1926, LL.B. 1929, Fordham University. Member of the New York Bar. Author of Understanding Lazor (McGraw-Hill 1945). Industrial Relations Director, Commcrce and Industry Association of New York, Inc., and editor of its "Annual Survey of Clerical Salary Rates and Personnel Practices" and of its publications in the field of personnel administration and labor relations. U. S. Chamber of Commerce designee on Labor-Management Advisory Committee of U. S. Conciliation Service, Region II. 
"faulty vision" (and it is indeed faulty) which underlies the illness; it will treat that which is substantive before treating the mere machinery of settlement. The application of the foregoing observations to the labor field may seem far-fetched. Let us, however, try to apply them concretely.

The general public and also strike statisticians have a very naive way of looking at the facts of a labor dispute. The general public's concept of a dispute is limited to the idea that the union is demanding certain rates of pay and the employer is insisting on certain lower rates of pay. Strike statisticians will limit their report of that situation by calling it a "wage dispute." Let us look at two historic strikes, each of which involved an apparently simple "wage dispute": the April, 1946, coal strike and the basic steel strike of 1946 . Have we any principles which will permit us to say whether Lewis was right in closing all the coal mines, or whether Murray was right in closing down the steel mills, and other enterprises, in support of their respective aims?

We have no such principles; we have never fully rationalized the subject. But are there not striking differences between the situations of Lewis and Murray which require recognition before any sound judgment can be passed? 'Most assuredly there are. Taking the case of Lewis first, let us attempt to understand his position by examining some strange conduct of his in connection with portal-to-portal pay.

In the operation of a coal mine it is necessary for the miners to report at the pithead or portal of the mine, pick up their lamps, tools and explosives and travel down the shaft on cars to the exposed end of the vein of coal on which they are working, called the "working face." In some mines this travel is very short, because the end of the vein is near the surface. But as coal is blasted out, the working face is pushed deeper and deeper into the mine, and in some of the older mines it takes more than two hours to travel back and forth between the face and the portal.

Now, until the defunct War Labor Board made its first "travel time" award, ${ }^{1}$ coal miners were never paid for this travel time. Their paid time started not when they reported at the pithead but when they reached the working face, and their paid time stopped when they left the working face on the return mantrip to the pithead, where they checked in their equipment before going home.

Is it not strange that strongly unionized employees should put in as much as two hours every day on company property and under company orders without getting paid for it? And is it not stranger still that when the Wage and Hour Administrator wanted to rule that travel time was working time and had to be counted toward the forty-hour week for overtime purposes, the United Mine Workers protested vehemently, insisted that travel time was not working time, and refused to let its members collect back pay for overtime? ${ }^{2}$

To find the explanation for this strange union conduct we shall have to examine

IIlinois Coal Operators Ass'n., II WAR LAB. REP. 687 (I943).

' See the dissenting opinion of Mr. Justice Jackson in Jewell Ridge Coal Corp. v. Local No. 6167, United Mine Workers of America, 325 U. S. I61, I70 (1944), esp. the note at 183-I87. 
this portal-to-portal issue a little further. After the "wage freeze" was clamped on in 1942, Mr. Lewis needed an argument to secure a wage increase. He seized upon this unpaid travel time, went to the War Labor Board, and argued, "My men are not getting paid for travel time. You must increase their wages by taking them off the 'face-to-face' pay basis and putting them on the 'portal-to-portal' pay basis." The War Labor Board ruled that miners were entitled to be paid for travel time.

But the trick in the travel-time award was this: under the award, employers were not to compute the time of each individual miner, nor, indeed, the travel time of each individual mine, and pay the employees according to the actual travel time. Oh, no! They were to compute the travel time in all competing mines, strike an average travel time among all those mines, and pay each employee that average travel-time allowance. So that a miner on a new vein where the travel time is ten minutes may get a travel allowance of forty-five minutes, but a miner in old diggings, where the working face is in the next county and there are two hours of travel in and out, still gets only forty-five minutes travel time.

Now it can be seen what Mr. Lewis is doing. He is trying to produce a parity of labor cost among all competing mines. Why? Because coal is what we lawyers call a fungible commodity, a commodity replaceable in kind. One ton of a given grade is about as good as any other ton of the same grade, and any differential in the selling price, however small, will sell the product of one mine over the product of another. The labor cost in coal mining is directly and powerfully related to the selling price, so that Lewis must, as nearly as he can, keep the labor cost equal among all competing mines, to avoid wrecking the price structure of the industry. If the price structure were wrecked, the colliery companies would have to compete by cutting wage rates-and that would be the end of the United Mine Workers.

It is obvious that such a union scheme absolutely prohibits any freedom of choice on the part of employees. Monopoly is the keystone of its operation. All of the competing mines must be subject to the standards established by the United Mine Workers, or the whole structure will fall apart. If the employees of the $A$ mine want a different union with different standards they cannot be permitted to have it. The United Mine Workers must keep their coal off the market-by mass picketing, by boycotting, by any means at their disposal. And the record in the famous Coronado case ${ }^{3}$ will show that in order to keep scab-dug coal out of the Central Competitive Field some fairly rough means were resorted to. Almost any coal-mine labor case will show that the United Mine Workers are very much less interested in the organization of employees as such than in keeping the coal dug in non-conforming mines off the market.

This being the case, the United Mine Workers must, of necessity, in any dispute with the mine owners, strike the entire competing section of the industry (which means the commercial, but not necessarily the captive mines). In no way other

${ }^{3}$ Coronado Coal Co. v. United Mine Workers of America, 268 U. S. 295 (1925). 
than by unitary action can the competitive parity which lies at the basis of the system be maintained. Hence there is at least a reason, if not a justification, for an industry-wide shutdown of the commercial mines.

Now let us contrast the situation of the United Steelworkers, who shut down the basic steel industry (and such unrelated industries as the production of paper milk containers). The Steelworkers exhibit no nice regard for maintaining competitive parity between one producer and another. There was no timorousness in the Steelworkers about filing portal-to-portal pay suits, no effort to spread the burden of travel time equally among competitors.

The reasons for this lack of concern over the competitive situation in the steel industry are readily apparent. In the first place, production-engineering differences between competitors make parity unattainable. One producer manufacturing sheet or plate on a continuous strip mill can turn out his product at a paltry fraction of the labor cost of a competing company rolling by older methods. In the second place, competitive parity, even if attainable, is of little consequence to the union or to the companies because the products do not come into such violent price competition. Competition in steel is not the penny-matching competition found in coal; it is a matter involving specification, patented products and processes, salesmanship and service.

Since there is no vital industry-wide relationship to be maintained by the Steelworkers, why in the 1946 basic steel strike did they choose to shut down the whole industry? The answer is, apparently, that because there is no vital industry-wide relationship, the Steelworkers Union is an organization which tends to fly apartto segmentize into CIO, AFL and independent and non-union shops; consequently its leadership, to "glue" it together, is alert to find industry-wide issues: The first genuine industry-wide (practically nation-wide) issue was provided by the cutback of production at the end of the war, and the leadership grasped that issue to give the constituent shops of the union an identity of interest, however arbitrary, and thus conquer the tendency to segmentize which exists because there is no natural industrywide relationship binding together the labor of the steel industry.

Was Mr. Murray justified in shutting down all the steel mills? Certainly Mr. Lewis had a much more tenable justification for shutting down all the coal mines.

The point here is not to justify nor to condemn the acts of either Lewis or Murray. It is to point out that, while the unions in olved have radically different functions to perform, the law gives exactly the same powers to both unions. The result is that one or both will have some powers which are non-functional and hence arbitrary. The mind of man cannot devise satisfactory settlements of disputes arising out of the use of arbitrary powers.

Apply this to concrete issues. If Lewis obtains a wage increase of, say, eighteen cents per ton at one mine, there is a good reason why other mines should grant the same increase. But when Murray obtains an increase of eighteen cents per hour 
at one mill, there is no compelling reason why other mills should pay a like increase. Why should not other mills pay ten cents, or thirty cents?

Take another issue. Lewis can demand a union shop on the ground that, since there is an industry-wide problem to be solved, the employees of each mine are bound by. an interest which transcends their relationship with their individual employer; at the same time, when he gets a union shop he acquires, by the very nature of his undertaking, the responsibility of treating all employers and employees alike. But Murray undertakes to do no more than deal with the relationship between the employees of one mill and their employer, and if he is granted a union shop he acquires no responsibility whatever.

The first step to be taken to provide satisfactory methods of dispute settlement must be taken by Congress. That step does not consist in the passage of restrictive legislation to curb the evils which have been impressed upon the public mind by experience; it consists rather in a re-examination of the fundamentals of unionism.

At one time or another in our labor history, popular and legal approval have been given to three distinct and mutually inconsistent objects of unionism:

I. The standardization of journeymen's pay rates and other working conditions in a local area (craft unionism);

2. The removal of wage-rate differentials as an identifiable factor in the pricing of competitive goods (old-line industrial unionism);

3. The achieving of maximum benefits for employees in relation to their own employer without special reference to the remainder of the craft or to the employer's competitors (elective unionism).

Craft unionism is ideally a monopoly of the labor market; old-line industrial unionism is ideally a monopoly of employers whose goods are competing; elective unionism, which is the creature of the Wagner Act, ${ }^{4}$ is, ideally, anti-monopolistic, since it depends on the free choice of employees in different bargaining units. It does not take any great acumen to see that such institutions are mutually contradictory in principle and that if the law recognizes and supports all three in identical fields conflict must result. Moreover, all three institutions will be unstable and labor leaders will, consequently, be driven to extreme measures to maintain the integrity of their respective organizations, as demonstrated by Mr. Murray's basic steel strike.

The attainment of differing objectives requires structurally different forms of organization. If you desire to attain the objective of craft unionism you must secure closed shops and industry-wide bargaining; you must prohibit dual unionism, working non-union, and working below scale; you must endeavor to prohibit nonunion men from working within your territorial and trade jurisdiction; you must always act as "the Craft," a principal, and never permit your organization to be reduced to a mere bargaining agent. If you desire to attain the objective of old-line industrial unionism, you should secure union shops, keep scab goods from competing

- 49 STAт. 149 (1935), 29 U. S. C. $5 \times 51$ et seq. (1940). 
with union goods, endeavor to maintain parity of labor costs whether certain groups of employees like it or not, and always act as "the Industry," never permitting your organization to be reduced to the status of a mere bargaining agent. If you wish to attain the objectives of elective unionism, you need not worry about closed shops or industry-wide bargaining, and you can safely act as agent for the shop which is your concern of the moment. The greater disparity (on the high side) you achieve over other comparable bargaining units, the better off you will be; and your one major concern will be to please your constituents (unless, of course, you can control them by maintenance-of-membership requirements).

Our friends who work at the physical sciences draw pictures to illustrate and differentiate the phenomena which they observe. While it is a bit more difficult to treat sociological phenomena than, for instance, atomic phenomena in this way, the drawings depicting the ideas of craft unionism (Fig. I), old-line industrial unionism (Fig. II), and elective unionism (Fig. III), will impress upon the reader the radical differences among these institutions.

Such differing institutions require different organic law. The primary move toward improving the national record in the -settlement of disputes must be taken by Congress, which, after adequate study, should tell us which of the three objectives are in accord with public policy, and which policy is to be followed in which field of endeavor. Is the craft union principle better in the building trades? Then apply the anti-trust exemption ${ }^{5}$ and the anti-injunction acts to that field and get rid of the contradictory Wagner Act in that field. Is the old-line industrial union better in the garment trades and the coal mines? Then abolish the mirage of freedom created by the Wagner Act and bolster in that field the old-line industrial union principle by such enactments as the Clayton Act $^{6}$ and the Norris-LaGuardia Act. ${ }^{7}$ Is the principle of elective unionism better in those fields of commerce and manufacture where craft standards are impractical and meaningless and labor-cost parity unattainable? Then, in those fields, abolish the closed shop, facilitate the ouster of nonrepresentative unions by their electorates, and reduce the union to the status of $a$ mere bargaining agent with no policies of its own, but those only which each shop unit has desired.

To the foregoing extent at least must the law undertake the settlement of labor disputes, enforcing its decrees by normal legal procedures.

We now turn to a discussion of the mechanics of dispute settlement, what has previously been called the "aspirin." The underlying institution of the frec-enterprise system is the mutually advantageous contract. A contract is a meeting of the minds of parties on the respective undertakings of each. If minds have not met, they may be assisted to come to a meeting but it is impossible to make them meet.

" 38 Stat. 73 I (rgi4), is U. S. C. \$i7 (r940).

- 38 STAT. 738 (1914), 29 U. S. C. 552 (1940), limiting the use of injunctions in labor disputen.

' 49 STAT. 70 (r932), 29 U. S. C. 5 Ior et seq. (2940). 


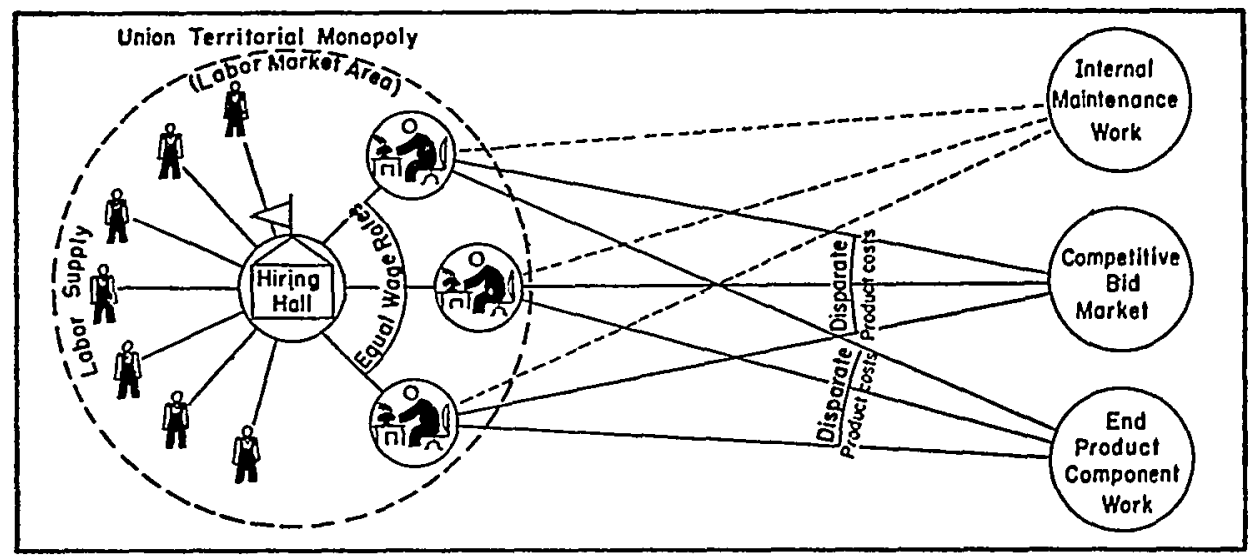

Figure I. IDEA OF CRAFT UNION

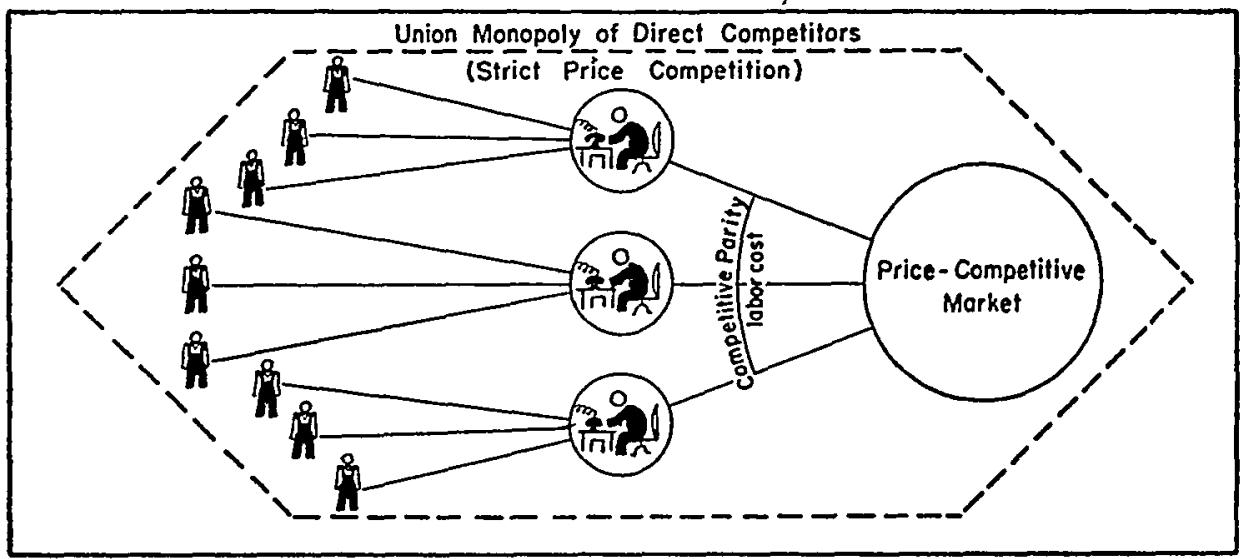

FIgure II. IDEA OF OLD-LINE INDUSTRIAL UNION

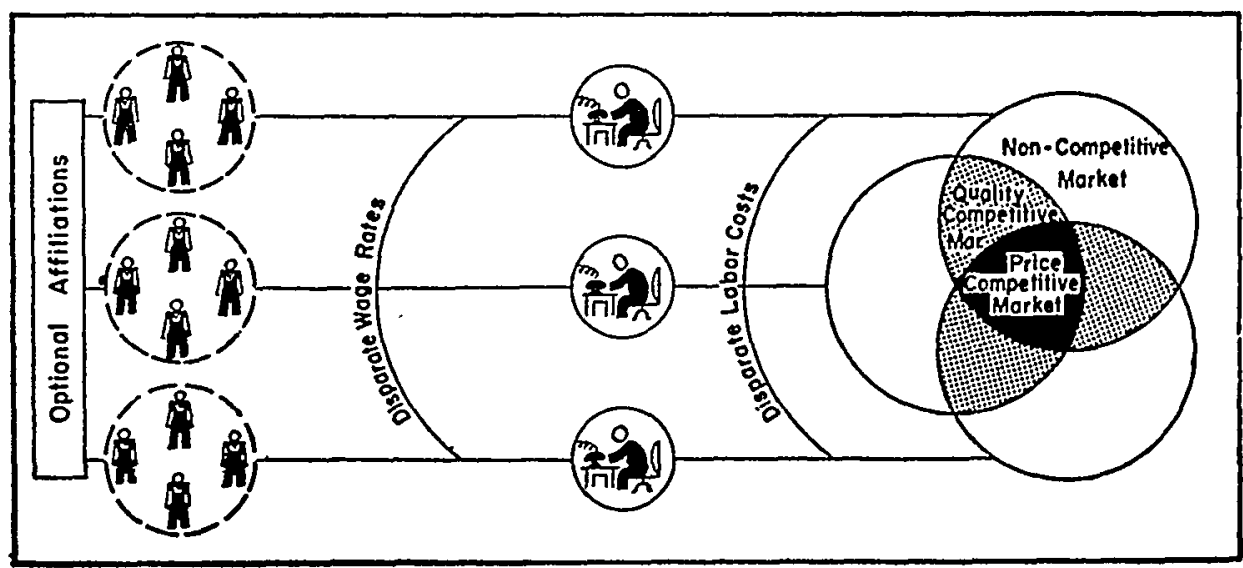

Figure III IDEA OF ELECTIVE UNION 
And it is as simple as that. No scheme, whether it be denominated "labor courts" or "compulsory arbitration" or called by any other name, which prescribes the conditions under which men must engage in mutual enterprise is consonant with the free-enterprise system.

The argument for labor courts and for compulsory arbitration thus has a fatal handicap. But this is not the only handicap, for experience in War Labor Board days has demonstrated that even when backed by the powerful moral suasion of the war the fiats of the board did not stop strikes and were, in many cases, the active producing cause of strikes.

The word "fiats" is used advisedly. It is an error to confound the notion of voluntary arbitration, wherein the parties have the ability to define the subject-matter submitted to arbitration so that the award or decision may be kept within tolerable limits, with the misnamed "compulsory arbitration" (it should be called "particularized labor legislation by random legislators") wherein the subject matter is unlimited and the manner in which the business interest and the labor interest are to be administered is determined by a person having no responsibility either to capital or to labor.

It is likewise an error to assume that "labor courts" will perform a judicial function. Their function, too, will be legislative because there are no standards within which they can be confined as judges are confined. And even if it were possible to create standards, which it is not, it would be undesirable to create them, because standards in this field paralyze progress and tend affirmatively to create labor strife by rendering inflexible that which should be flexible-the ability of capital and labor to adjust themselves rapidly to changing conditions.

Finally, compulsory arbitration and labor courts would interfere with our productivity. A labor court may dictate wages, but it can never make an employee cooperative in production; it may prescribe hours, but it can never make employees render service with a smile. Our standard of living is high not because we have greater natural resources; other nations have more than we. It is high because we, more than any other nation, have recognized that there is a spiritual force in manhis free will-which if left unfettered is potent to overcome all obstacles. Our production system is based upon this force: we must win the co-operation of men, not compel it. To the extent to which a system of compulsion supplants a system of volition we lose this force, and the result will be individual bankruptcy and national setback.

There are, in the case of certain utilities and certain basic industries, some apparently powerful arguments for abolishing collective bargaining and substituting compulsory arbitration. (It may be noted, in passing, that this is precisely what would happen: compulsory arbitration absolutely destroys collective bargaining; it can never be a "terminal point" in collective bargaining.) However powerful this argument of the "common good" may appear, it is always the short-term "com- 
mon good" which is meant, never the long-range "common good." In such industries other solutions than compulsory arbitration must be sought. For example, if the trouble is monopoly, break down the monopoly; if a natural monopoly is involved, consider seizure and the provision of substitute service.

There is one idea which the writer advances very diffidently as a substitute for compulsory arbitration in the utility field. This is based upon the predicate that the employees and the management in that field have the duty of serving the public. More specifically, they have the obligation to arrive at mutually satisfactory terms of employment in order to serve the public. If they default in their obligation, the consuming public is damaged. Let the consuming public, therefore, recoup its damages from the parties who have failed to make the necessary agreement. Since there is no way of apportioning the damage as between employer and employec, let them both contribute in equal amounts. Perhaps the threat of such loss following upon a strike would furnish an adequate incentive for agreement, and the threat could be made a certainty by formalization of the procedure. Procedural provisions could be devised which would prevent the employees from visiting their share of the damages upon the employer by the simple process of increasing their demands. While the impossibility of apportioning the damages makes one pause, it may be remarked that the idea has certain points of similarity with the treatment of the multiple-employer problem under the workmen's compensation laws and also with the admiralty collision rules.

Another idea, again advanced very diffidently, involves a technique which avoids the vice of compulsory arbitration. This idea might be called "supervised bargaining," and is based upon an extension of the notion of section $8(5)$ of the Wagner Act, ${ }^{8}$ which imposes upon the employer the duty of bargaining in good faith. As it stands in the Wagner Act the provision is one-sided and more or less futile as an instrument of industrial peace because it attempts to answer the somewhat academic question, "What unlawful conduct of the employer several months ago stood in the way of agreement?" If, however, the obligation were made bilateral by including the union, and if the proceeding were transferred from the NLRB to a court with chancery powers, and if the investigation were directed at the present conduct of the parties rather than at their past acts, the proceeding might become an instrument of industrial peace. The bargaining process is often stymied by unlawful demands or by evasions or by misconstruction of words. A court could determine what demands are unlawful, what conduct is evasive, and it could put binding constructions on words. The writer recalls a case wherein a union objected to an employer's job descriptions but would neither advance descriptions of its own nor point out wherein the employer's descriptions were in error, nor even inspect the plant to determine what the correct descriptions were. Such conduct could be readily corrected by a judicial authority operating "on the spot" with adequate powers not

- 49 STAT. 452 (1935), 29 U. S. C. \$158(5) (1940). 
to compel agreement but to eliminate misunderstanding, lack of good faith, and illegality. If, in addition, at the conclusion of its proceedings it were authorized, in its discretion, to submit the final offer of the employer directly to the employees, some strife might be prevented. A procedure of "supervised bargaining" may hold some promise.

The "cooling-off" period has gained some popular favor. Most of the men in labor and in industry who deal directly with industrial relations believe this device to be more an illusion than a solution. This is so because the moment a cooling-off period is imposed upon the parties it becomes a strategy factor in negotiation, a card to be played at the proper time by one or the other of the parties. This is true whether the period precedes or follows the breakdown of negotiations. If a party knows that a cooling-off period will follow the breakdown, he will not concede as much prior to the breakdown, in order that he may sound out the temper of his opposition; and this type of dealing will cause more breakdowns, and probably more strikes. The probable potency of the cooling-off period as a strike preventive is so small that its enactment into law is unjustified.

One constructive piece of legislation that could be attempted, however, is a requirement that parties notify the United States Conciliation Service either of the opening of negotiations or of the breakdown thereof. There is a feeling among some labor relations men that an appeal to the Conciliation Service is a sign of weakness which might prejudice their bargaining positions. The statutory requirement that such notice be given would cure this reluctance to call: in a third party.

What to do about the Conciliation Service is today a mooted question. The fact that the Department of Labor is by statute a partisan of labor creates a good deal of doubt as to its impartiality in the administration of the Service, and the actual experience of many management men with conciliation commissioners, particularly on such issues as union security, has tended to confirm the suspicion that, either in its method of selecting personnel or in its method of training, the pro-labor bias has played some part. Even if the Labor Department were not a statutory partisan, there is considerable doubt of the wisdom of leaving the Conciliation Service subject to one of the political departments of the Government where it may be used as an instrument of Administration policy. The proper disposition of the Service is probably to constitute it an independent agency. The idea of having the Service administered by a governing committee composed of labor and of management representatives (no "public" representatives) is worth exploring. The function of the governing committee should be limited so that it would not itself enter into the settlement of disputes but would merely select and direct the personnel of the Service.

The idea of a "mediation board," meaning a body vested with the function of direct and active participation in the settlement of labor disputes, has some currency today. Such an institution would not only be less efficient than the system of media- 
tion and conciliation by individual commissioners, but it would be fraught with danger to the parties and to the public. The acts of such a board would, like those of the ill-conceived fact-finding commissions, tend to start "patterns" which would create and intensify disputes elsewhere in our economy.

Legislation can never furnish a panacea for industrial ills, but it is a mistake to think that nothing can be accomplished by legislation. The laboratory of legal science is a hard laboratory; but if we persist in working out our experiment in freedom, keeping our substance away from the acids of foreign ideologies, there is no reason why we cannot ultimately achieve substantial industrial justice and a fair measure of industrial peace. 